ISSN 0258-7122

Bangladesh J. Agril. Res. 35(1) : 143-148, March 2010

\title{
EFFECT OF HARVESTING TIME ON YIELD AND YIELD ATTRIBUTES OF CHICKPEA (Cicer arietinum L.)
}

\author{
A. KHATUN ${ }^{1}$, M.A.H.BHUIYAN ${ }^{2}$ \\ A. NESSA ${ }^{3}$ AND S.M. BYAZIED HOSSAIN ${ }^{4}$
}

\begin{abstract}
Field experiments were carried out during 2004-2006 at Bangladesh Agricultural Research Institute Farm in Grey Terrace Soils, Agro-Ecological Zone (AEZ 28), Joydebpur, Gazipur, Bangladesh to determine the effects of harvesting time on yield and yield attributes of chickpea. Chickpea seeds of three varieties viz., BARI Chola-5, BARI Chola-6, and BARI Chola-8 were collected at three times viz., i) when the pods were yellowish with a few yellow greens $\left(\mathrm{H}_{1}\right.$ stage $)$, ii) when most of the pods were light brown with a few yellow $\left(\mathrm{H}_{2}\right.$ stage), and iii) when all the pods were completely brown and dry $\left(\mathrm{H}_{3}\right.$ stage). All the seeds were stored in earthen pot until conducting the field study. Significant variation was not observed in three varieties of chickpea for most of the parameters studied. The highest pods/plant, seeds/pod, and seed yield were observed in BARI Chola-5 and the lowest in BARI Chola-8. Seeds collected at the stage when most of the pods were light brown with a few yellow $\left(\mathrm{H}_{2}\right.$ stage) recorded the highest pods/plant, seeds/pod, 1000-seed weight and seed yield. The highest seed yield was recorded from BARI Chola-5 when seeds were collected at $\mathrm{H}_{2}$ stage.
\end{abstract}

Keywords: Chickpea, harvesting time, yield, yield attributes.

\section{Introduction}

Seed development and maturation study is important because the seeds may be harvested to ensure good yield associated with viability, vigour and field performance (Dharmalingam and Basu, 1990). Physiological changes might set in, if the seeds are retained on the mother plant for longer duration after physiological maturity which would lead to the development of hard seeds or offcolour seeds in pulse crops. Moisture content of harvested crop affects seed quality and hence it determines with which moisture content the crop should be threshed. Harvesting at high moisture content increases the chances of mycofloral infection on seed, while harvesting at low moisture content increases mechanical damage to seed (Yadav et al., 2005). Early harvested seeds were immature and poorly developed and as such are poor storers compared to seed

\footnotetext{
${ }^{1}$ Senior Scientific Officer, Planning and Evaluation Division, BARI, Joydebpur, Gazipur1701, ${ }^{2}$ Senior Scientific Officer, Soil Science Division, BARI, Joydebpur, Gazipur-1701, ${ }^{3}$ Principal Scientific Officer, Seed Technology Division, BARI, Joydebpur, Gazipur1701, ${ }^{4}$ Curator, Training and Communication Wing, BARI, Joydebpur, Gazipur-1701, Bangladesh.
} 
harvested at physiological maturity (Mahesha et al., 2001). Seed yield and quality largely depends on the stage of maturity (Kumar et al., 2002). As such, harvesting of seeds at right stage of maturity is most important since harvesting either at early or late stage results in lower yields with poor quality seeds. So, the experiment was conducted to determine the effects of harvesting time on yield and yield attributes of chickpea.

\section{Materials and Method}

Field experiments were carried out at the Research Field of Pulse Research Centre, Bangladesh Agricultural Research Institute (BARI), Joydebpur, Gazipur, Bangladesh during rabi season of 2004-05 and 2005-06. The area belongs to the Agro-ecological Zone (AEZ 28) under Madhupur Tract. The experimental site is situated at $24.00^{\circ}$ North Latitude and $90.26^{\circ}$ East Longitude. Chickpea seeds of three varieties viz., BARI Chola-5 $\left(\mathrm{V}_{1}\right)$, BARI Chola-6 $\left(\mathrm{V}_{2}\right)$, and BARI Chola-8 $\left(\mathrm{V}_{3}\right)$ were collected earlier from Pulses Research Centre experimental field in rabi seasons of 2003-04 considering three different times at 7-day intervals, viz. i) when the pods were yellowing with a few yellow greens $\left(\mathrm{H}_{1}\right.$ stage), ii) when most of the pods were light brown with a few yellow $\left(\mathrm{H}_{2}\right.$ stage), and iii) when all the pods were completely brown and dry $\left(\mathrm{H}_{3}\right.$ stage). The collected seeds were preserved in the earthen pot. Thousand-seed weight of BARI Chola-5, BARI Chola-6 and BARI Chola-8 were 120 g, 145 g, and 190 g, respectively. Before setting up the field experiment, laboratory experiment was carried out for recording the seed quality data (Khatun et al., 2009).

Field experiments were conducted with the above seeds. The experiments were conducted in a factorial randomized completely block design. The row to row spacing was $30 \mathrm{~cm}$ and plant to plant $10 \mathrm{~cm}$. The unit plot size was $3 \mathrm{~m} \mathrm{x} 4$ m. Seeds were sown on 17 November 2004 and 11 November 2005. Yield attributes and yield were recorded. The data for different characters were compiled and tabulated in proper form and then subjected to statistical analysis following a computer package programme IRRISTAT and mean differences were adjudged with Duncan’s Multiple Range Test.

\section{Results and Discussion}

Pods/plant: Number of pods plant was directly related to seed yield. BARI Chola-5 produced higher pods/plant, which resulted in higher seed yield (Table 1 ), though number of pods/plant did not differ significantly among the varieties. Bhingarde and Dumbre (1993) reported that large sized seed gave higher number of pods/plant (21.9 pods) and smaller size seed gave lower pods/plant (20.5) in mungbean. Borate et al. (1993) observed that pods/plant was higher (19.2) in large size seeds and lower (12.9) in small size seed of groundnut. Harvesting stage showed significant difference in number of pods/plant only in 2005-06 
where maximum pods were recorded from $\mathrm{H}_{2}$ stage, which was similar to $\mathrm{H}_{3}$ stage (Table 2). Interaction effects of variety and harvesting stage were significant in pods/plan where the highest number of pods/plant (40.3 in 2004-05 and 40.8 in 2005-06) was observed in $\mathrm{H}_{3}$ stage of BARI Chola-5 and the lowest number of pods/plant was observed in $\mathrm{V}_{3} \times \mathrm{H}_{3}$ in both the years (Table 3).

seeds/pod: Number of seeds/pod significantly differed among the varieties in 2004-05 (Table 1). Bhingarde and Dumbre (1993) reported that large sized seed gave higher number of seeds/pod (8.1 seed) and smaller size seed gave lower seeds/pod (7.5 seed) in mungbean. The highest seeds/pod was observed in $\mathrm{H}_{2}$ stage (Table 2). Variety x harvesting stage on seeds/pod was statistically identical (Table 3) though numerically the highest number of seeds/pod (1.77 in 2004-05 and 1.75 in 2005-06) was noted in $\mathrm{V}_{1} \mathrm{x} \mathrm{H}_{2}$.

Table 1. Effects of different varieties of chickpea on seed yield and its attributes.

\begin{tabular}{|c|c|c|c|c|c|c|c|c|}
\hline \multirow{2}{*}{ Varieties } & \multicolumn{2}{|c|}{ Pods/plant } & \multicolumn{2}{|c|}{ Seeds/pod } & \multicolumn{2}{|c|}{ 1000-seed wt (g) } & \multicolumn{2}{|c|}{ Seed yield (kg/ha) } \\
\hline & 2004-05 & 2005-06 & 2004-05 & 2005-06 & 2004-05 & 2005-06 & 2004-05 & 2005-06 \\
\hline $\begin{array}{l}\text { BARI } \\
\text { Chola-5 }\end{array}$ & 32.7 & 35.8 & 1.69a & 1.67 & 130c & $135 c$ & 1136a & $1101 \mathrm{a}$ \\
\hline $\begin{array}{l}\text { BARI } \\
\text { Chola-6 }\end{array}$ & 30.2 & 33.8 & $1.53 \mathrm{~b}$ & 1.61 & $153 b$ & $155 b$ & $958 b$ & $941 b$ \\
\hline $\begin{array}{l}\text { BARI } \\
\text { Chola-8 }\end{array}$ & 28.2 & 32.8 & $1.54 b$ & 1.53 & $192 a$ & 189a & 832c & 812c \\
\hline SE $( \pm)$ & - & - & 0.4 & - & 3.44 & 2.55 & 35.4 & 17.5 \\
\hline $\begin{array}{l}\text { Level of } \\
\text { Sig. }\end{array}$ & ns & ns & $*$ & ns & $* *$ & $* *$ & $* *$ & $* *$ \\
\hline
\end{tabular}

In a column, means values having common letters are not significantly different as per DMRT.

*significant at 5\% level, **significant at 1\% level, ns: Not significant.

1000-seed weight: Thousand-seed weight of three chickpea varieties differed significantly (Table 1). Maximum seed weight (192 g in 2004-05 and $189 \mathrm{~g}$ in 2005-06) was obtained in BARI Chola-8. Borate et al. (1993) observed that 1000 -seed weight was higher (235 g) in large size seeds and lower (197 g) in small size seed of groundnut. Thousand-seed weight ranged from 110-120 g in BARI Chola-5, 140-150 g in BARI Chola-6, and 250-260 g in BARI Chola-8 was observed by Bakr et al. (2002). Harvesting stage did not show significant effect in 1000-seed weight (Table 2). The interaction effect of variety $\mathrm{x}$ harvesting stage was not significant in respect of 1000-seed weight (Table 3). This might be due to similar response of different varieties with harvesting stage. However, apparently thousand-seed weight was the highest in $\mathrm{V}_{3} \mathrm{x} \mathrm{H}_{2}(198 \mathrm{~g}$ in 
2004-05 and $195 \mathrm{~g}$ in 2005-06) and it was the lowest in $\mathrm{V}_{1} \mathrm{x} \mathrm{H}_{1}$ in 2004-05 and $\mathrm{V}_{1} \mathrm{x} \mathrm{H}_{2}$ in 2005-06.

Table 2. Effects of chickpea seeds collected from different harvesting stages on seed yield and its attributes.

\begin{tabular}{|c|c|c|c|c|c|c|c|c|}
\hline \multirow{2}{*}{$\begin{array}{l}\text { Harvesting } \\
\text { stage }\end{array}$} & \multicolumn{2}{|c|}{ Pods/plant } & \multicolumn{2}{|c|}{ Seeds/pod } & \multicolumn{2}{|c|}{ 1000-seed wt (g) } & \multicolumn{2}{|c|}{ Seed yield (kg/ha) } \\
\hline & 2004-05 & 2005-06 & 2004-05 & 2005-06 & 2004-05 & 2005-06 & 2004-05 & 2005-06 \\
\hline $\mathrm{H}_{1}$ & 29.0 & 31.3b & $1.49 b$ & $1.48 \mathrm{~b}$ & 156 & 156 & $881 b$ & 874 \\
\hline $\mathrm{H}_{2}$ & 31.6 & $36.4 a$ & $1.64 \mathrm{a}$ & 1.68a & 161 & 163 & 1079a & 1081 \\
\hline $\mathrm{H}_{3}$ & 30.6 & $34.6 \mathrm{ab}$ & 1.63a & $1.65 a$ & 159 & 160 & 966ab & 899 \\
\hline $\mathrm{SE}( \pm)$ & - & 0.89 & 0.042 & 0.055 & - & - & 35.4 & - \\
\hline $\begin{array}{l}\text { Level of } \\
\text { Sig. }\end{array}$ & ns & $* *$ & $*$ & $*$ & ns & ns & $* *$ & ns \\
\hline
\end{tabular}

In a column, mean values having common letters are not significantly different as per DMRT.

*significant at 5\% level, **Sjgnjficant at $1 \%$ level, ns: Not significant.

Table 3. Interaction effects of chickpea varieties and seeds collected from different harvesting stages on seed yield and its attributes.

\begin{tabular}{|c|c|c|c|c|c|c|c|c|}
\hline \multirow{2}{*}{$\begin{array}{c}\text { Interaction } \\
(\mathrm{V} \times \mathrm{H})\end{array}$} & \multicolumn{2}{|c|}{ Pods/plant } & \multicolumn{2}{|c|}{ Seeds/pod } & \multicolumn{2}{|c|}{ 1000-seed wt (g) } & \multicolumn{2}{|c|}{ Seed yield (kg/ha) } \\
\hline & 2004-05 & 2005-06 & 2004-05 & 2005-06 & 2004-05 & $2005-06$ & 2004-05 & 2005-06 \\
\hline $\mathrm{V}_{1} \mathrm{xH}_{1}$ & $25.7 \mathrm{~b}$ & $28.5 \mathrm{c}$ & 1.70 & 1.62 & 129 & 135 & $1073 b c$ & $1029 \mathrm{~b}$ \\
\hline $\mathrm{V}_{1} \mathrm{xH}_{2}$ & $32.0 \mathrm{ab}$ & $38.2 \mathrm{ab}$ & 1.77 & 1.75 & 130 & 132 & 1393a & 1353 a \\
\hline $\mathrm{V}_{1} \mathrm{xH}_{3}$ & $40.3 \mathrm{a}$ & $40.8 \mathrm{a}$ & 1.60 & 1.65 & 131 & 137 & 942bcd & $920 \mathrm{~cd}$ \\
\hline $\mathrm{V}_{2} \mathrm{xH}_{1}$ & $29.7 \mathrm{~b}$ & 32.7 bc & 1.37 & 1.43 & 152 & 150 & 859cde & $883 \mathrm{~d}$ \\
\hline $\mathrm{V}_{2} \mathrm{xH}_{2}$ & $33.0 \mathrm{ab}$ & $35.5 \mathrm{abc}$ & 1.60 & 1.68 & 154 & 161 & 929bcd & 959 bc \\
\hline $\mathrm{V}_{2} \mathrm{xH}_{3}$ & $28.0 \mathrm{~b}$ & $33.1 \mathrm{~b}$ & 1.63 & 1.73 & 153 & 153 & $1085 b$ & 980 bc \\
\hline $\mathrm{V}_{3} \mathrm{xH}_{1}$ & $31.7 \mathrm{~b}$ & 32.8 bc & 1.40 & 1.39 & 186 & 182 & $711 \mathrm{e}$ & $709 \mathrm{f}$ \\
\hline $\mathrm{V}_{3} \mathrm{XH}_{2}$ & $29.7 \mathrm{~b}$ & $35.5 \mathrm{abc}$ & 1.57 & 1.62 & 198 & 195 & 9l6bcd & $930 \mathrm{~cd}$ \\
\hline $\mathrm{V}_{3} \mathrm{xH}_{3}$ & $23.3 \mathrm{~b}$ & $30.0 \mathrm{c}$ & 1.67 & 1.58 & 192 & 190 & 869cde & 798 e \\
\hline $\mathrm{SE}( \pm)$ & 2.91 & 1.54 & - & - & - & - & 61.3 & 30.4 \\
\hline $\begin{array}{l}\text { Level of } \\
\text { Sig. }\end{array}$ & * & $* *$ & ns & ns & ns & ns & $* *$ & $* *$ \\
\hline CV (\%) & 16.5 & 7.8 & 8.0 & 10.3 & 6.5 & 4.8 & 10.9 & 5.5 \\
\hline
\end{tabular}

In a column, mean values having common letters are not significantly different as per DMRT.

*significant at 5\% level, **Significant at $1 \%$ level, ns: Not significant.

Seed yield: Different varieties of chickpea varied significantly in terms of seed yield (Table 1). The highest seed yield (1136 kg/ha in 2004-05 and $1101 \mathrm{~kg} / \mathrm{ha}$ in 2005-06) was recorded in BARI Chola-5. BARI Chola-5 produced the highest 
pods/plant, seeds/pod, which resulted in the highest seed yield. BARI Chola-6 recorded the second highest seed yield (958 kg/ha in 2004-05 and $941 \mathrm{~kg} / \mathrm{ha}$ in 2005-06) and BARI Chola-8 gave the minimum yield (832 kg/ha in 2004-05 and $812 \mathrm{~kg} / \mathrm{ha}$ in 2005-06). Harvesting stage increased significantly the seed yield of chickpea only in 2004-05 (Table 2). The highest seed yield was obtained in $\mathrm{H}_{2}$ stage. The increase in yield in $\mathrm{H}_{2}$ stage compared to $\mathrm{H}_{1}$ was $22.5 \%$ in 2004-05 and 23.7\% in 2005-06 which might be attributed to increased pods/plant, seeds/pod and 1000-seed weight (Rani and Kodandaramaiah, 1997; Bhuiyan, 2004). Mehta et al. (1993) conducted experiment with two chickpea varieties, namely H-75-35 and HK-88-232, and seeds were harvested at seven times (15, 22, 19, 33,37,41,45 days after anthesis i.e., DAA). They observed that fresh weight of seed increased progressively upto 33 and 37 DAA in cvs. H-7535 and HK-88-232, respectively, and subsequently fresh weight rapidly declined. They also reported that seeds harvested at 37 DAA recorded the highest dry weight of seeds when seeds collected at the stage when most pods were light brown with a few yellow green stages. The present findings are in agreement with the findings of Mehta et al. (1993). Mehta et al. (1993) also stated that all the cultivars attained maximum dry matter accumulation (physiological maturity) at $\mathrm{H}_{2}$ stage thereafter, dry weight of seed decreased because of restricted supply of nutrients from mother plant to seed due to disruption of vascular connection and utilization in various physiological and metabolic processes like respiration etc. Interaction effect of varieties and harvesting stage was significant for seed yield (Table 3). BARI Chola-5 gave the highest seed yield at $\mathrm{H}_{2}$ stage. BARI Chola-8 gave the lowest seed yield at $\mathrm{H}_{1}$ stage.

The overall results revealed that the highest pods/plant, seeds/pod and seed yield were observed in BARI Chola-5 and the lowest in BARI Chola-8. Seeds collected at the stage when most of the pods were light brown with a few yellow $\left(\mathrm{H}_{2}\right.$ stage) recorded the highest pods/plant, seeds/pod, 1000-seed weight, and seed yield. BARI Chola- 5 seeds collected at $\mathrm{H}_{2}$ stage recorded the highest seed yield.

\section{References}

Bakr, M. A., K. H. M. Siddique and C. Johansen. 2002. Integrated management of botrytis grey mould of chickpea in Bangladesh and Australia. Summary Proceedings of a Project Inception Workshop. 1-2, June 2002, Bangladesh Agricultural Research Institute, Joydebpur, Gazipur, Bangladesh. pp. 22-23.

Bhingarde, M. T. and A. D. Dumbre. 1993. Effect of seed size on growth and yield components in greengram (Vigna radiata L. Wilczek) under summer conditions. Seed Res. 21(2): 104-106.

Bhuiyan, M. A. H. 2004. Evaluation of introducing mungbean into cereal based cropping pattern for sustainable soil fertility and productivity. Ph.D. Thesis. Department of Soil Sci. Bangladesh Agricultural Univ., Mymensingh, Bangladesh. 
Borate, D. N., A. D. Dumbre and M. T. Bhingarde. 1993. Effect of seed size on growth, yield and seed quality of groundnut (Arachis hypogaea L.) under summer conditions. Seed Res. 21(2): 107-109.

Dharmalingam, C. and R. N. Basu. 1990. Seed development and maturation studies in mungbean. Seed Res. 6: 101-109.

Kumar, V., S. D. Shahidhan, M. B. Kurdikeri, A. S. Channaveeraswami and R. M. Hosmani. 2002. Influence of harvesting stages on seed yield and quality in paprika (Capsicum annuum L.). Seed Res. 30(1): 99-103.

Mahesha, C. R., A. S. Channaveeraswami, M. B. Kurdikeri, M. Shekhargouda and M. N. Merwade. 2001. Seed maturation studies in sunflower genotypes. Seed Res. 29(1): 95-97.

Mehta, C. J., M. S. Kuhad, I. S. Sheoran and A. S. Nandwal. 1993. Studies on seed development and germination in chickpea cultivars. Seed Res. 21(2): 89-91.

Rani, B. P. and D. Kodandaramaiah. 1997. Response of soybean (Glycine max) to inoculation with varying nitrogen levels. Indian J. Agron. 42(1): 135-137.

Yadav S. K., S. Yadav, P. R. Kumar and K. Kant. 2005. A critical overview of chickpea seed technological research. Seed Res. 33(1): 1-15. 